\title{
Spinal Cord Ischemia Related to Disc Herniation: Case Report and a Review of the Literature
}

\author{
Marlien W Aalbers' \\ Rob JM Groen $\mathbb{D}^{\prime}$ \\ Auke PA Appelman ${ }^{2}$ \\ Thea DJ Heersema ${ }^{3}$ \\ Beatrijs HA Wokke ${ }^{4}$ \\ DL Marinus Oterdoom ' \\ 'Department of Neurosurgery, \\ University Medical Center Groningen, \\ Groningen, The Netherlands; \\ ${ }^{2}$ Department of Radiology, University \\ Medical Center Groningen, Groningen, \\ The Netherlands; ${ }^{3}$ Department of \\ Neurology, University Medical Center \\ Groningen, Groningen, The Netherlands; \\ ${ }^{4}$ Department of Neurology, Erasmus \\ Medical Center, Rotterdam, The \\ Netherlands
}

Correspondence: DL Marinus Oterdoom Department of Neurosurgery, University Medical Center Groningen, Hanzeplein I, PO Box 30000I, Groningen, 9700 RB,

The Netherlands

Tel +3I $5036 \mid 2837$

Fax +3I 503611715

Email d.I.m.oterdoom@umcg.nl

\begin{abstract}
Symptoms of spinal cord ischemia can mimic myelopathy due to spinal cord compression in the acute phase. Thoracic disc herniation with limited spinal cord compression but rapid progression of neurological symptoms causes a clinical dilemma as to whether emergency decompression should be performed. We report a case of acute progressive myelopathy due to spinal cord ischemia related to thoracic disc herniation initially managed by Th8 laminectomy with reduction of the herniated disc. Repeat imaging showed T2weighted hyperintensity in the posterior cord. The clinical and radiological course supports posterior spinal artery ischemia. This case illustrates and a review of the literature shows that thoracic disc herniation may be complicated by ischemic myelopathy even in the absence of cord compression.
\end{abstract}

Keywords: acute myelopathy, vascular supply spinal cord

\section{Introduction}

Acute myelopathies constitute a challenging clinical problem with a broad differential diagnosis including autoimmune, inflammatory, infectious and (para) neoplastic etiologies. In the case of progressive neurologic deficits due to myelopathy caused by spinal cord compression, acute surgical decompression may be required, leaving limited time for analysis. We report a case of acute myelopathy that turned out to be due to spinal cord ischemia (SCI), presumably (partly) caused by thoracic disc herniation. We describe the evolution of the clinical and magnetic resonance imaging (MRI) pattern, illustrating the challenging clinical decision-making process and underlining this relatively rare but important differential diagnosis.

\section{Case Report}

A 54-year-old Caucasian female without relevant medical history noticed acute paresthesias and mild weakness of the left leg in the evening before admission. When she awakened at night she noticed that the weakness had progressed and that she had lost control of bladder function. On admission, she also complained of acute severe pain on the thorax, paresthesias and weakness of the right leg, and she reported diffuse pain in the left leg. In the weeks previous to presentation she had been experiencing a different sensation on the left side of her thorax. Clinical exam revealed an atactic paresis of the left leg graded 4/5 on the MRC scale. Tendon reflexes were pathologically increased in the lower limbs, and Babinski's response was absent. There was a loss of superficial sensation below the T6 dermatome, most pronounced on the left side, and there was diminished sense of vibration, touch and 
position in the left leg. Her sphincter pressure was decreased, and there was $150 \mathrm{~mL}$ residue after micturition.

Spinal MRI showed a calcified Th8-9disc herniation which slightly indented the anterior cord without cord abnormalities (Figure 1). The paresis progressed to grade 1 of the left leg and grade 2 of the right leg within two hours. Emergency laminectomy of the eighth thoracic vertebra was performed that same night. Due to rapid deterioration no further (time-consuming) diagnostic procedures (eg additional imaging) were carried out prior to surgery. The partly calcified disc was removed through a transpedicular approach until there was no more spinal cord compression. Surgery was uneventful. Of note, because of the emergency setting, intra-operative neuromonitoring was not available. The day after surgery the paresis improved slightly, and there was no further deterioration of neurological function. Repeat MRI performed the day after surgery demonstrated multiple hyperintense intramedullary lesions (Figure 1). Therefore, acute myelitis (possibly neuromyelitis optica spectrum disease, NMOSD) was considered as a differential diagnosis, and treatment with high- dose intravenous methylprednisolone was initiated, followed by oral maintenance dose. Repeat MRI 10 days after symptom onset revealed a clearly demarcated T2 hyperintense lesion in the posterior cord extending from the fifth to the tenth thoracic vertebrae, with partial contrast enhancement (Figure 1). Cranial MRI was normal.

The results of additional laboratory exams including erythrocyte sedimentation rate, C-reactive protein, vitamin B12, angiotensin-converting enzyme, and thyroidstimulating hormone. Serology for CMV, EBV, Lyme, and Treponema pallidum and thyroperoxidase, thyroglobulin, antinuclear, anti-extractable nuclear antigen, antineutrophil cytoplasmic, lupus anticoagulant, aquaporin-4 (AQP4), myelin oligodendrocyte glycoprotein (MOG) and paraneoplastic antibodies were within normal limits or negative. Visual evoked potentials showed delayed latencies (p100: left $120 \mathrm{~ms}$, right $122 \mathrm{~ms}$ ). The last-mentioned finding led to a possible diagnosis of neuromyelitis optica (NMO), and the patient was started on azathioprine for long-term immunosuppression. However, repeat ophthalmologic exam revealed no abnormalities,

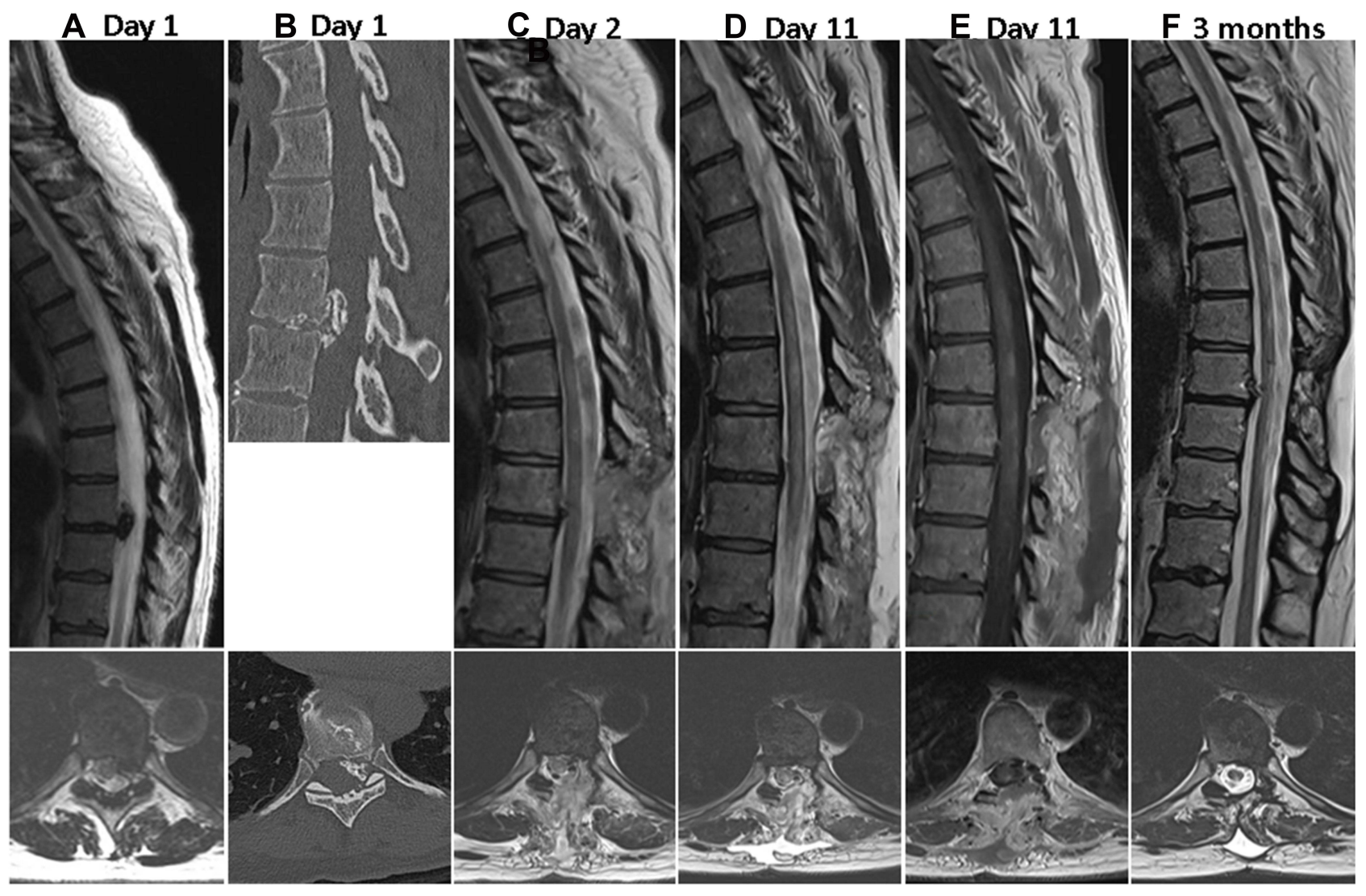

Figure I Evolvement of imaging finding. T2-weighted (A, C, D and F) and TI-weighted contrast- enhanced (E) magnetic resonance images and CT-image (B). (A and B) Day I: calcified Th8-9 disc herniation without cord abnormalities; (C) Day 2 (post-surgery): multiple hyperintense intramedullary lesions; (D) Day II: T2 hyperintense lesion in the posterior cord (E) that shows partial contrast enhancement; (F) 3 Months: cord abnormalities have decreased. 


\section{Spinal arterial anatomy}

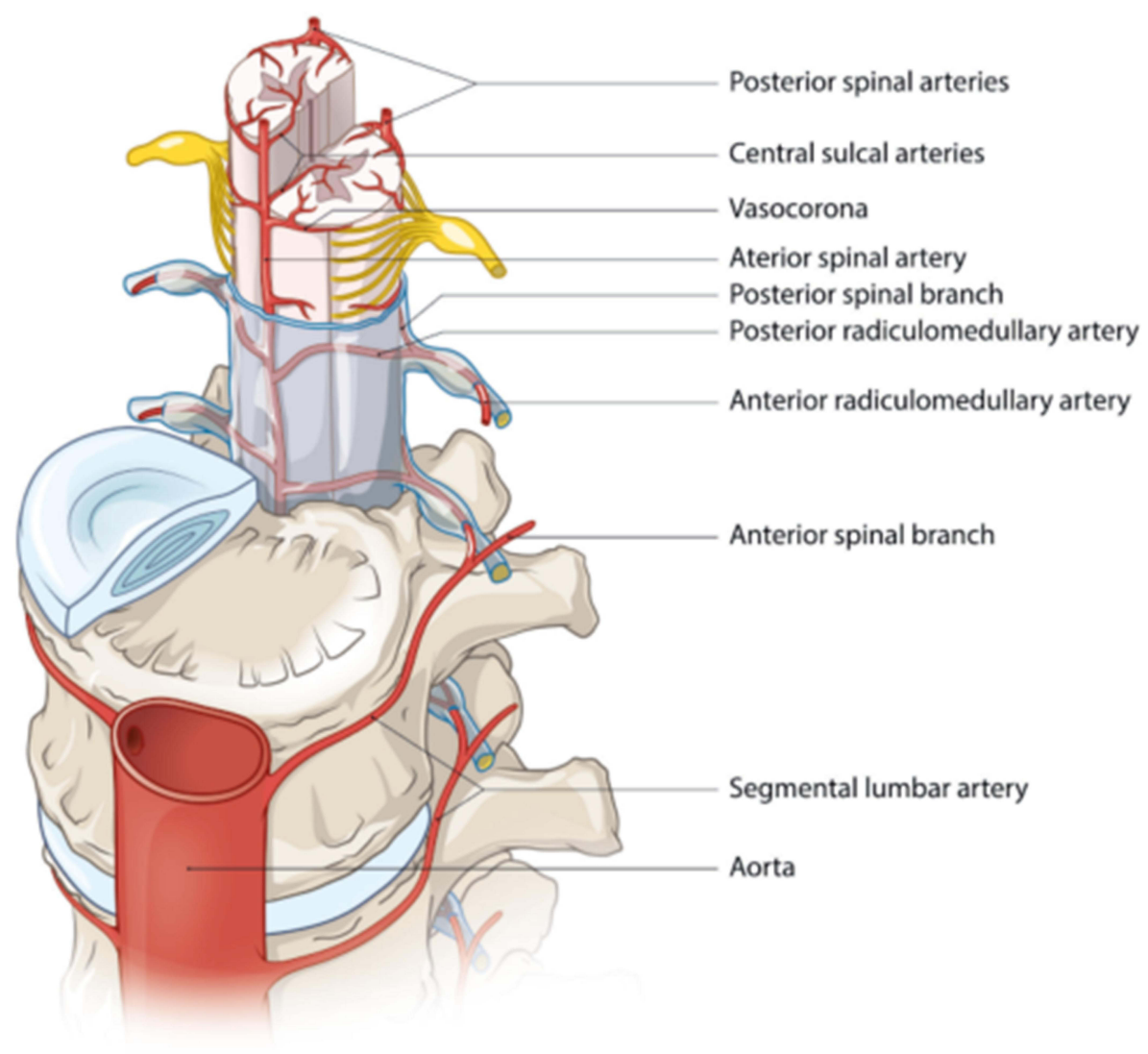

Figure 2 Schematic drawing of the vascular network supplying the spinal cord.

and cerebrospinal fluid (CSF) analysis showed normal cell count, mild elevation of protein levels and no oligoclonal bands. Therefore the azathioprine was discontinued. At this point, the patient was referred for a second opinion, and spinal cord ischemia was established as the most likely diagnosis.

The patient was transferred to the division of rehabilitation. After three months the patient was able to walk short distances with a walker. MRI showed a marked decrease in cord abnormalities, and contrast enhancement was no longer present (Figure 1). Written informed consent was obtained from the patient for publication of this case report. Institutional approval was not required to publish the case details.

\section{Discussion}

This case underlines the clinical dilemma of acute myelopathy. Spinal cord ischemia as the most likely diagnosis was only considered after repeat MRI and unremarkable results of CSF analysis. Retrospectively, the acute pain and onset of neurological symptoms and stepwise deterioration should have been considered in the differential diagnosis.

Our case meets the proposed criteria for probable SCI by Zalewski et al. ${ }^{1}$ The bilateral motor deficit with predominantly lemniscal sensory deficit is consistent with posterior spinal artery ischemia.

In the present case radiologic features further support SCI. First of all, the spatial and temporal distribution of T2 signal is in line with a posterior infarct that is characterized by involvement of posterolateral regions. ${ }^{2,3}$ The first MRI was normal, while T2 abnormalities appeared after hours, and finally contrast enhancement was present after days. Diffusion-weighted imaging (DWI) can be used to differentiate ischemic from inflammatory myelopathies, but unfortunately this sequence was not acquired in this case. However, even though DWI has become increasingly 
sensitive for the diagnosis of spinal cord ischemia, its sensitivity is lower than in the brain. In clinical practice, DWI may have a contributory role, but patient history, MRI and CSF analysis are to date the mainstay in the diagnosis of SCI.

The spinal cord ischemia might have been caused by disruption of one of the radicular arteries. Radicular arteries are part of the intricate arterial network that supplies the spinal cord. One anterior and two posterior spinal arteries course longitudinally along the spinal cord surface and are interconnected by the vasa corona surrounding the spinal cord. They originate from the vertebral and posterior inferior cerebellar arteries, respectively. The spinal arteries are further supplied by the radicular arteries that derive from segmental arteries including the ascending cervical, intercostal and lumbar arteries and run along the spinal roots through the intervertebral foramina (Figure 2).
A literature search was performed in PubMed using the following search terms: (posterior cord syndrome) OR (posterior spinal artery syndrome OR ischemic myelopathy) AND ("Intervertebral Disc Displacement”[Mesh] OR spinal disc herniation OR non compressive nucleus pulposus extrusion). To date, 9 cases of radicular artery occlusion due to thoracic disc herniation have been reported (Table 1$).^{4-11}$ Only in one other patient has a posterior spinal artery infarct due to thoracic disc herniation been described in a larger series of spinal stroke. ${ }^{12}$ Disc rupture may result in direct compression or stretching of the radicular artery, resulting in spasm or occlusion. Indeed, in several cases direct compression of the radicular vessel was demonstrated either during surgery or by spinal angiography. ${ }^{4-6}$ However, acute compression in the present case is unlikely as the herniated disc was calcified and therefore presumably already present for a longer period.

Table I Overview of Literature on Spinal Cord Ischemia Due to Thoracic Disc Herniation

\begin{tabular}{|c|c|c|c|c|c|c|c|c|c|}
\hline Study & Age & Sex & $\begin{array}{l}\text { Disc } \\
\text { Herniation }\end{array}$ & Calcification & $\begin{array}{l}\text { Spinal } \\
\text { Artery } \\
\text { Syndrome }\end{array}$ & $\begin{array}{l}\text { Interval } \\
\text { Onset to } \\
\text { Nadir (h) }\end{array}$ & $\begin{array}{l}\text { Motor Deficit } \\
\text { (MRC Scale) }\end{array}$ & $\begin{array}{l}\text { Sensory } \\
\text { Deficit }\end{array}$ & $\begin{array}{l}\text { T2WI } \\
\text { Changes }\end{array}$ \\
\hline \multirow[t]{2}{*}{$\begin{array}{l}\text { Chiche } \\
2017^{5}\end{array}$} & 40 & $F$ & T6-7, T7-8 & + & Anterior & 2 & $O B$ & Vital B & $\begin{array}{l}\text { T3 to T8 } \\
\text { anterior }\end{array}$ \\
\hline & 57 & $\mathrm{~F}$ & TIO-TII & n.m. & Anterior & n.m. & Grade n.m. B & n.m. & $\begin{array}{l}\text { TIO and } \\
\text { below } \\
\text { anterior }\end{array}$ \\
\hline $\begin{array}{l}\text { Dolan } \\
2009^{8}\end{array}$ & 36 & $\mathrm{~F}$ & Th6-7 & n.m. & $\begin{array}{l}\text { Brown- } \\
\text { Sequard }\end{array}$ & 0.5 & $\mathrm{I}-2 \mathrm{R}$ & $\begin{array}{l}\text { Vital L, } \\
\text { gnostic R }\end{array}$ & $\begin{array}{l}\text { Lateral, } \\
\text { vertebral } \\
\text { body T7 }\end{array}$ \\
\hline $\begin{array}{l}\text { Guest } \\
2000^{7}\end{array}$ & 38 & $F$ & T8-9 & n.m. & Anterior & 5 & $\mathrm{I}-2 \mathrm{~B}$ & Vital B & $\begin{array}{l}\text { T5-6 to } \\
\text { TI0-II } \\
\text { anterior }\end{array}$ \\
\hline $\begin{array}{l}\text { Lopez- } \\
\text { Gonzales } \\
2011^{9}\end{array}$ & 45 & $\mathrm{~F}$ & T8-9 & + & Complete & 2 & $O B$ & $\begin{array}{l}\text { Complete } \\
\text { B }\end{array}$ & $\begin{array}{l}\text { T6 to conus } \\
\text { diffuse }\end{array}$ \\
\hline $\begin{array}{l}\text { Mansour } \\
1987^{4 *}\end{array}$ & 49 & $\mathrm{~F}$ & T9-10 & + & $\begin{array}{l}\text { Brown- } \\
\text { Sequard }\end{array}$ & 6 & n.m. B & Vital R & $\begin{array}{l}\text { Not } \\
\text { performed }\end{array}$ \\
\hline $\begin{array}{l}\text { Reynolds } \\
2014^{10}\end{array}$ & 36 & $F$ & T7-8 & - & Anterior & 12 & $2-4 \mathrm{R}, 0 \mathrm{~L}$ & Vital B & $\begin{array}{l}\text { T6-7, } \\
\text { anterior }\end{array}$ \\
\hline $\begin{array}{l}\text { Santillan } \\
2020^{6}\end{array}$ & 54 & $\mathrm{~F}$ & T8-9 & n.m. & Anterior & 24 & Grade n.m. B & $\begin{array}{l}\text { Vital, } \\
\text { gnostic B }\end{array}$ & $\mathrm{TI}-4$ \\
\hline $\begin{array}{l}\text { Yano } \\
2003^{11 * *}\end{array}$ & 78 & M & T8-9 & Unclear & Anterior & Unclear & $O B$ & Unclear & $\begin{array}{l}\text { T8-9 and } \\
\text { below }\end{array}$ \\
\hline
\end{tabular}

Notes: article only available in *French and **japanese.

Abbreviations: $F$, female; $M$, male; $n . m$., not mentioned; L, left; R, right; B, bilateral. 
Compression radiculopathy may result in structural changes that result in an insufficient anastomotic network, although the exact mechanism that results in SCI remains elusive.

\section{Conclusion}

In conclusion, in the present case, a vascular origin of myelopathy was only considered after surgical exploration, pharmacological treatment of NMOSD and various diagnostic tests. We argue that the emergency surgery is justifiable and maybe even indispensable considering the possibility that even in the absence of significant spinal cord compression, disc herniation can play a role in development of acute myelopathy. Also, administration of anti-inflammatory drugs while waiting for laboratory tests is reasonable as some inflammatory myelopathies can result in severe deficit if treatment is delayed. However, the differential diagnostic option of vascular origin of the pathology was only considered after a second review of the case, months after the initial event. The case underlines the difficulty and dilemmas that can be faced in SCI and is therefore relevant.

\section{Disclosure}

The authors report no conflicts of interest in this work.

\section{References}

1. Zalewski NL, Rabinstein AA, Krecke KN, et al. Characteristics of spontaneous spinal cord infarction and proposed diagnostic criteria. JAMA Neurol. 2018;75(12):1542-1545. doi:10.1001/jamaneurol.2018.2605
2. Novy J, Carruzzo A, Maeder P, Bogousslavsky J. Spinal cord ischemia. Arch Neurol. 2006;63(8):1113. doi:10.1001/archneur.63.8.1113

3. Alblas CL, Bouvy WH, Lycklama À Nijeholt GJ, Boiten J. Acute spinal-cord ischemia: evolution of MRI findings. J Clin Neurol. 2012;8(3):218. doi:10.3988/jen.2012.8.3.218

4. Mansour H, Hammoud F, Vlahovitch B. [Brown-Séquard syndrome caused by foramen and calcified disk herniation, responsible for direct compression of Adamkiewicz's artery]. Neurochirurgie. 1987;33(6):478-481. French.

5. Chiche L, Carlier R-Y, Siahou D, Nataf A, Hugeron C, Palazzo C. Spinal cord ischemia in Scheuermann disease: a report of three cases. Jt Bone Spine. 2017;84(3):345-348. doi:10.1016/j.jbspin.2016.10.007

6. Santillan A, Goldberg JL, Carnevale JA, Kirnaz S, Hartl R, Knopman J. Anterior spinal artery syndrome caused by thoracic disc herniation. J Clin Neurosci. 2020;77:211-212. doi:10.1016/j. jocn.2020.05.040

7. Guest JD, Griesdale DE, Marotta T. Thoracic disc herniation presenting with transient anterior spinal artery syndrome. Interv Neuroradiol. 2000;6(4):327-331. doi:10.1177/159101990000600408

8. Dolan R, Houston G, O'Riordan J. Brown-Séquard syndrome due to noncompressive disc prolapse and spinal cord infarction. QJM. 2009;102(3):225-227. doi:10.1093/qjmed/hen126

9. Lopez-Gonzalez A, Peris-Celda M. Acute paraplegia after chiropraxis. Eur Spine J. 2011;20(S2):S143-6. doi:10.1007/s00586010-1443-5

10. Reynolds JM, Belvadi YS, Kane AG, Poulopoulos M. Thoracic disc herniation leads to anterior spinal artery syndrome demonstrated by diffusion-weighted magnetic resonance imaging (DWI): a case report and literature review. Spine J. 2014;14(6):e17-e22. doi:10.1016/j. spinee.2013.10.050

11. Yano S, Hida K, Seki T, Iwasaki Y, Akino M, Saitou H. [A case of thoracic disc herniation with sudden onset paraplegia on toilet straining: case report]. Neurol Surg. 2003;31(12):1297-1301. Japenese.

12. Kumral E, Polat F, Güllüoglu H, Uzunköprü C, Tuncel R, Alpaydın S. Spinal ischaemic stroke: clinical and radiological findings and short-term outcome. Eur J Neurol. 2011;18(2):232-239. doi:10.1111/j.1468-1331.2010.02994.x
International Medical Case Reports Journal

\section{Publish your work in this journal}

The International Medical Case Reports Journal is an international, peer-reviewed open-access journal publishing original case reports from all medical specialties. Previously unpublished medical posters are also accepted relating to any area of clinical or preclinical science. Submissions should not normally exceed 2,000 words or 4

\section{Dovepress}

published pages including figures, diagrams and references. The manuscript management system is completely online and includes a very quick and fair peer-review system, which is all easy to use. Visit http://www.dovepress.com/testimonials.php to read real quotes from published authors. 